Proc. Estonian Acad. Sci. Biol. Ecol., 2001, 50, 3, 169-179

\title{
HISTORY OF INVESTIGATIONS ON THE ECOSYSTEM OF LAKE PEIPSI
}

\author{
Külli KANGUR ${ }^{\mathrm{a}}$, Juta HABERMAN ${ }^{\mathrm{a}}$, Andu KANGUR ${ }^{\mathrm{a}}$, Peeter KANGUR ${ }^{\mathrm{a}}$, \\ Anu MILIUS ${ }^{\mathrm{b}}$, Helle MÄEMETS ${ }^{\mathrm{a}}$, Reet LAUGASTE ${ }^{\mathrm{a}}$, and Ervin PIHU \\ ${ }^{\text {a }}$ Võrtsjärv Limnological Station, Institute of Zoology and Botany, Estonian Agricultural \\ University, 61101 Rannu, Tartumaa, Estonia; kkangur@zbi.ee; juta@zbi.ee; akangur@zbi.ee; \\ pkangur@zbi.ee; helle@zbi.ee; reet@zbi.ee \\ b Institute of Zoology and Botany, Estonian Agricultural University, Riia mnt. 181, 51014 Tartu, \\ Estonia; milius@zbi.ee
}

Received 28 March 2001, in revised form 11 June 2001

\begin{abstract}
The investigations of the biota in L. Peipsi, one of the largest lakes of Europe, started already one and a half centuries ago, complex studies were initiated in the 1930s. The paper gives a brief survey of research into the hydrochemistry, macrophytes, bacterio-, phyto- and zooplankton, zoobenthos, fishes, and fisheries management of the lake. Special attention is paid to the main findings. Intensive anthropogenic eutrophication of L. Peipsi started in the 1970s. The nutrient content reached its maximum in the 1980s and decreased thereafter. An expansion of reeds, increase in the similarity between different lake parts, and decline of rare macrophyte species have occurred. Regarding phytoplankton, L. Pihkva has become strongly eutrophic, whereas L. Peipsi s.s. has eutrophied to a smaller extent, its northern part has maintained a mesotrophic appearance. In 196599, the number but not the biomass of zooplankton increased. The number of small-sized zooplankters (especially rotifers) increased. No essential changes in the composition and distribution of macrozoobenthos in connection with eutrophication of the lake were observed. Dreissena polymorpha, introduced accidentally in the lake in the 1930s, has become the most significant animal population in L. Peipsi. Considering annual fish catches L. Peipsi surpasses all large lakes in North Europe. The main commercial fishes are smelt, perch, pikeperch, roach, bream, pike, and until the 1990s also vendace. At present it is changing into a smelt-bream-pikeperch lake.
\end{abstract}

Key words: hydrochemistry, macrophytes, bacterioplankton, algae, zooplankton, zoobenthos, fisheries management.

\section{INTRODUCTION}

Lake Peipsi (L. Peipus, Pskovsko-Chudskoe ozero in Russian) is located on the border of the Republic of Estonia and the Russian Federation. It is one of the 
largest lakes in Europe $\left(3555 \mathrm{~km}^{2}\right)$. The lake consists of three parts: the largest and deepest northern part L. Peipsi s.s., the middle strait-like part L. Lämmijärv, and the southern part L. Pihkva (L. Pskov; Fig. 1). The mean depth of the lake is $7.1 \mathrm{~m}$ and the residence time of water is about two years. There are about 240 inlets into L. Peipsi. The largest rivers are the Velikaya, the Emajõgi, the Võhandu, and the Zhelcha. The outflow, the Narva River, runs its waters into the Gulf of Finland.

The water of L. Peipsi is relatively rich in nutrients: the mean concentrations of total $\mathrm{P}$ and $\mathrm{N}$ are 43 and $670 \mathrm{mg} \mathrm{m}^{-3}$, respectively. Both the amount of wastewater discharged into water bodies as well as pollution load have decreased markedly in recent years owing to progress in wastewater treatment and decrease in diffuse pollution from agricultural lands (Loigu et al., 1999).

The productivity of L. Peipsi can be considered quite high. Its fish catches surpass those of all large lakes of North Europe.

Investigations of the biota in L. Peipsi started already in the middle of the 19th century. In certain periods (1918-40 and from 1992 onwards) L. Peipsi has been divided between two different countries (Estonia and Russia), which has hindered coordinated observations on the whole lake. However, the composition of the biota and its changes have been studied by researchers of both countries. Comprehensive investigations of the biota of L. Peipsi started in the Russian part of the lake in the 1930s (Sokolov, 1941; Petrov, 1947). After World War II the ecosystem of the lake was studied by the All-Union Research Institute of River and Lake Fisheries (VNIORKh, since 1959 GosNIORKh; Leningrad, Pskov) and the Pskov Pedagogical Institute.

On the Estonian side, the Institute of Zoology and Botany (IZB) of the Estonian Academy of Sciences (since 1997 of the Estonian Agricultural University) has made its contribution to comprehensive hydrobiological and ichthyological investigations on L. Peipsi since 1962. From the 1990s, hydrobiological monitoring on the lake (macrophytes, bacterio-, phyto- and zooplankton, macrozoobenthos) has been performed under the leadership of IZB. The results have been published in monographs (Pihu \& Raukas, 1999; Pihu \& Haberman, 2001). The biota of the lake has been studied also by the Estonian Marine Institute, the University of Tartu, and other research establishments.

\section{HYDROCHEMICAL STUDIES}

First information on the chemical composition of water in L. Peipsi was published in Sankt-Peterburg by Spindler \& Sengbusch (1896). Sokolov (1941) provided more hydrochemical data on the lake in the middle of the 1930s. Systematic hydrochemical studies on the lake started in 1950 at the station of Tiirikoja (near Mustvee) and have continued up to now.

A hydrochemistry database was created by the hydrochemistry team of IZB on the basis of data from different sources. We used periodical issues of the 


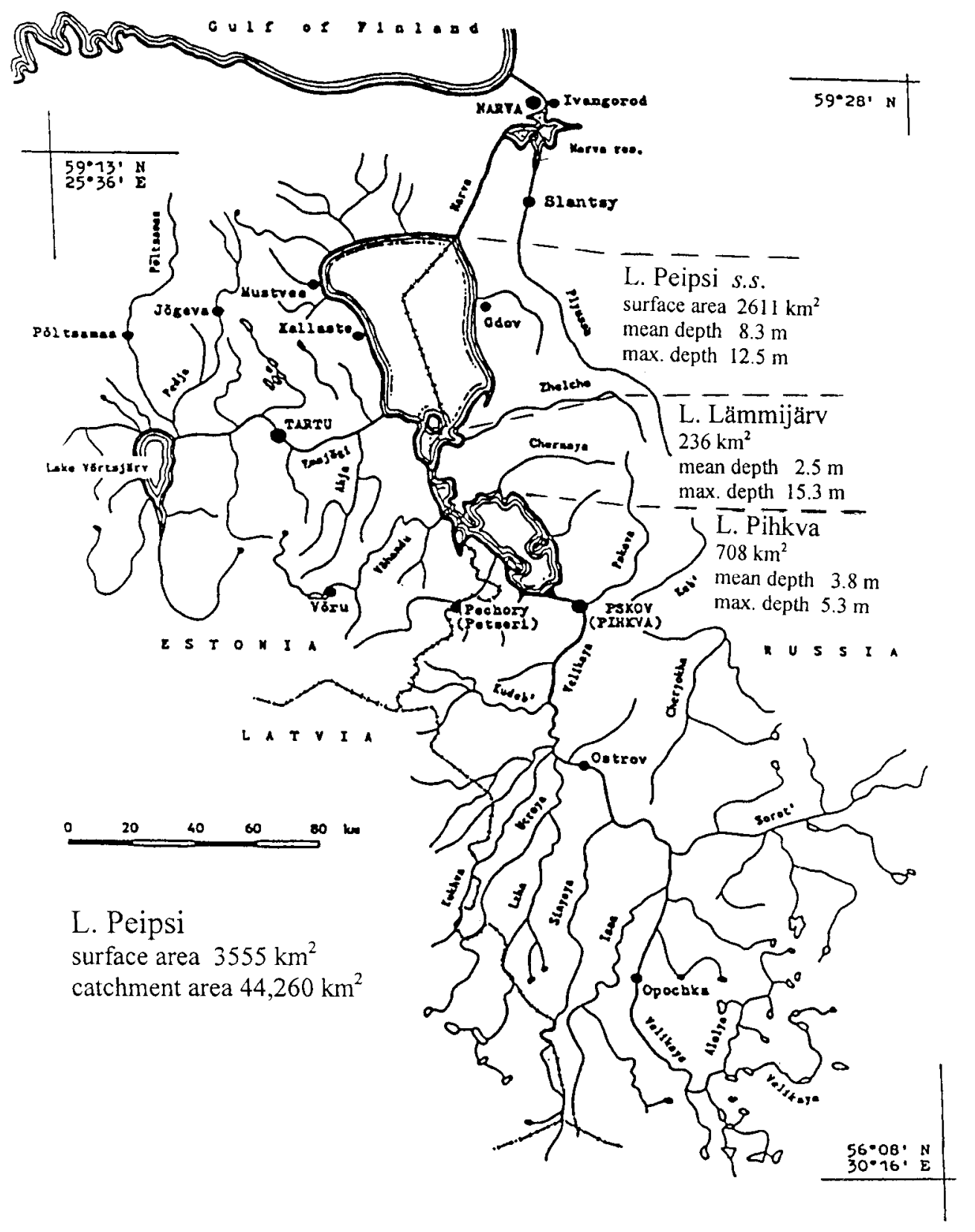

Fig. 1. Lake Peipsi and its catchment area (after Jaani \& Raukas, 1999). 
Hydrometeorological Service (Tallinn, Leningrad) from 1950-90. In 1950-75 the number of sampling sites on the lake varied from 3 to 41, later from 14 to 25 (Kaputerko, 1983). In 1985-92 the analyses were made by IZB and in 1992-96 by the Tartu Environmental Researchers Ltd. Monthly field observations were carried out from May to November in 1985-90 and only in the Estonian side of the lake in 1992-96, with 9-19 sampling sites located in L. Peipsi s.s., 2-6 in L. Lämmijärv, and 1-7 in L. Pihkva.

Until 1985, major ions of mineral origin $\left(\mathrm{HCO}_{3}{ }^{-}, \mathrm{SO}_{4}{ }^{2-}, \mathrm{Cl}^{-}, \mathrm{Ca}^{2+}, \mathrm{Mg}^{2+}, \mathrm{K}^{+}\right.$, $\left.\mathrm{Na}^{+}\right)$; organic matter as chemical oxygen demand by dichromate $\left(\mathrm{COD}_{\mathrm{Cr}}\right)$ and permanganate $\left(\mathrm{COD}_{\mathrm{Mn}}\right)$ oxidizability; water colour $(\mathrm{Col})$; inorganic phosphorus and nitrogen compounds $\left(\mathrm{PO}_{4}{ }^{3-}, \mathrm{NO}_{3}^{-}, \mathrm{NO}_{2}^{-}, \mathrm{NH}_{4}{ }^{+}\right)$; soluble $\mathrm{Si}$; total $\mathrm{Fe}$; dissolved $\mathrm{O}_{2} ; \mathrm{pH}$; and transparency of water (SD) were investigated. Four comprehensive hydrochemical surveys on the lake have been compiled (Simm, 1975; Kaputerko, 1983; Nazarov, 1984; and Starast et al., 1999).

In 1985 IZB joined the research programme of L. Peipsi. The content of $\mathrm{N}_{\text {tot }}$, $\mathrm{P}_{\text {tot }}, \mathrm{Chl} a, \mathrm{O}_{2}, \mathrm{COD}_{\mathrm{Cr}}, \mathrm{COD}_{\mathrm{Mn}}, \mathrm{pH}, \mathrm{Col}$, and $\mathrm{SD}$ were determined. Intensive anthropogenic eutrophication of L. Peipsi had started in the 1970s (Starast et al., 1999). The aim of the studies was to study thoroughly the causes of rapid eutrophication and find out possibilities of restraining harmful changes. The contents of $\mathrm{N}_{\mathrm{tot}}, \mathrm{NO}_{2}^{-}, \mathrm{NH}_{4}{ }^{+}, \mathrm{P}_{\mathrm{tot}}, \mathrm{PO}_{4}{ }^{3-}, \mathrm{Fe}, \mathrm{Si}, \mathrm{Chl}, \mathrm{COD}_{\mathrm{Cr}}, \mathrm{COD}_{\mathrm{Mn}}$, and $\mathrm{Col}$ decrease from south (L. Pihkva) to north (L. Peipsi s.s.), while SD, $\mathrm{HCO}_{3}{ }^{-}, \mathrm{SO}_{4}{ }^{2-}$, $\mathrm{Cl}^{-}, \mathrm{Ca}^{2+}, \mathrm{Mg}^{2+}$, and $\mathrm{NO}_{3}{ }^{-}$have an opposite trend. The values of $\mathrm{pH}, \mathrm{O}_{2}$, and $\mathrm{O}_{2} \%$ are quite uniform all over the lake. A mathematical method of fast monitoring was elaborated for describing regional and temporal changes in the chemical variables of lake water (Möls \& Saan, 1991). Several new statistical concepts were introduced to cope with the data unbalance problems (Möls et al., 1996).

\section{MAIN INVESTIGATIONS OF THE BIOTA OF LAKE PEIPSI}

\section{General brief chronology}

1. 1851-52: four fishery expeditions by K. E. von Baer, St. Petersburg (Baer, 1860).

2. 1909, 1912: phyto- and zooplankton by N. Samsonov, Tartu University (Samsonov, 1912, 1914).

3. 1912-13: smelt and other commercial fishes by I. Kuznetsov and others from St. Petersburg.

4. 1935-41: complex investigations in the eastern part of the lake by A. Sokolov, V. Petrov (Sokolov, 1941; Petrov, 1947), and others, Leningrad.

5. 1951-91: complex investigations in the whole lake, since 1992 up to now in the Russian part of the lake by P. Tyurin, N. Malashkin, L. Perminov, E. Afanas'ev, and others; VNIORKh, GosNIORKh, Leningrad, Pskov. 
6. 1962-91: complex annual investigations of the biota; since 1992 in the Estonian part of the lake by IZB, Tartu; Võrtsjärv Limnological Station (LS), Tartu County.

7. Since 1997 up to now: applied fishery investigations in the Estonian part of the lake by Estonian Marine Institute, University of Tartu.

\section{Macrophytes}

\section{Studies}

1. Before World War II, only a few brief surveys, descriptions of shore sections, and floristic comments were compiled. In the 1940s problems of the overgrowing of L. Pihkva were under study (V. Ivanov, Pskov).

2. 1962-63: Tuvikene (1966) from ZBI described the macrophytes of the whole lake.

3. 1966-70: Nedospasova (1974) from Pskov described the macrophytes of the whole lake and estimated their biomass.

4. 1970-71 and 1980: Aime Mäemets (Võrtsjärv LS) described twice the macrophytes in the whole lake and in 1986-87 in the main northern and western inflows.

5. 1988-89: Sudnitsyna (Sudnitsõna, 1990) from Pskov estimated the biomass of macrophytes and described the macrovegetation of the eastern, southern, and southwestern coasts of the lake.

6. 1997-2000: H. Mäemets (Võrtsjärv LS) described the macrophytes of the Estonian coast and estimated the biomass of submerged vegetation (Mäemets \& Mäemets, 2001).

\section{Main changes}

1. In the 1960s the species composition was complemented with more nutrient-demanding species, especially in the northern part of the lake. The peak diversity of the 1970s decreased to the 1980s as a result of disappearance of more sensitive species. Impoverishment of the species composition has been continuing in recent decades (Mäemets \& Mäemets, 2001).

2. Expansion of reeds caused the levelling of differences in the macrovegetation between lake parts. Associations with Phragmites australis, Schoenoplectus lacustris, and Potamogeton perfoliatus dominating prevail everywhere. The common growth depth of submerged species has recently been $2 \mathrm{~m}$, in a few places up to $4 \mathrm{~m}$ (NW corner).

3. By the end of the 1980s the enormous biomasses of P. perfoliatus - over $660 \mathrm{~g}$ air-dry matter per $\mathrm{m}^{2}$ at the end of the $1960 \mathrm{~s}$ - decreased tenfold. Recently the biomass of this species has stayed at the level of the 1980s. The biomasses of Phragmites and Schoenoplectus increased between the 1960s and 1980s many (7-39) times. 


\section{Bacterioplankton}

\section{Studies}

1. 1962: first samples of water for microbiological analyses from L. Peipsi were collected by Aime Mäemets, systematical investigations were started in 1980 by S. Lokk, Võrtsjärv LS; V. Tohver and others, University of Tartu.

2. 1985-87: microbiological analyses of the main inflows (10 rivers) and the outflow of the lake were made (Lokk \& Kisand, 1996).

3. Since 1992 the monitoring of microbiology has been carried out in the Estonian part of the lake (Lokk et al., 2001).

\section{Main conclusions}

Regarding the total number of bacteria L. Peipsi s.s. has mesotrophic features with a tendency to eutrophy in its southern part $\left(2.4 \times 10^{6}\right.$ cells $\left.\mathrm{mL}^{-1}\right)$, while L. Lämmijärv and L. Pihkva are eutrophic $\left(>3.9 \times 10^{6}\right.$ cells $\left.\mathrm{mL}^{-1}\right)$. Regarding coliforms and the number of Enterococcus the lake is in a good sanitary state (Lokk et al., 2001).

\section{Studies}

\section{Phytoplankton} 1896).

1. 1895: the first note about the algae of L. Peipsi (Spindler \& Sengbusch,

2. 1909 and 1912: seasonal qualitative data on phytoplankton (Samsonov, 1912, 1914).

3. 1929 and 1934: seasonal qualitative data on phytoplankton by S. Ganeshin and N. Voronikhin, Leningrad (Voronikhin, 1950).

4. Diatom analysis of sediments by N. Davydova, Institute of Lake Research, Leningrad (Davydova, 1985).

5. 1962-91: systematic quantitative studies of phytoplankton in the whole lake, particularly in July or August, by R. Laugaste, M. Pork, and I. Ott, Võrtsjärv LS.

6. 1992 up to now: seasonal studies; only Estonian part of the lake has been sampled (Võrtsjärv LS).

7. 1983, 1985-2000: pigment analysis, seasonal studies by A. Milius and T. Nõges, Võrtsjärv LS, IZB.

8. 1970-94: primary production measurements by Pskovian researchers (Bessonov \& Vasil'ev, 1975; Yastremskij, 1983).

9. 1985-87, 1992, 1997-98: primary production measurements by P. Nõges, Võrtsjärv LS (Nõges et al., 1996).

10. 1970-91: seasonal studies on phytoplankton in the whole lake by Pskovian researchers; 1992 up to now: seasonal studies; only Russian part of the lake by V. Yastremskij, Pskov (Laugaste et al., 2001).

\section{Main changes}

1. Since 1962 the average summer biomass has fluctuated up to 10 times (in the range 3-34 $\mathrm{g} \mathrm{m}^{-3}$ ) in L. Peipsi s.s. and $>20$ times $\left(5.6-125 \mathrm{~g} \mathrm{~m}^{-3}\right.$ ) in 
L. Pihkva. Periods of high biomass coincide with warm periods and low water (the middle of the 1960s, the first half of the 1970s, the end of the 1980s, and the 1990s).

2. Until the 1960s the lake parts showed evident differences in dominant species. Later the species composition has been levelling out, but differences in biomass have increased.

3. Fluctuations in biomass and chlorophyll $a$ content have become sharper, their peaks are higher and more frequent.

4. Indicator species of highly eutrophic water bodies (Aphanizomenon flosaquae (L.) Ralfs, Anabaena spp.) are spreading widely.

5. Regarding phytoplankton, L. Pihkva has become strongly eutrophic, whereas L. Peipsi s.s. has eutrophied to a smaller extent, its northern part has maintained a mesotrophic appearance.

\section{Zooplankton}

\section{Studies}

1. 1909 and 1912: Samsonov $(1912,1914)$ studied zooplankton.

2. Before World War II: studies by the Institute of Hydrology of the USSR (Leningrad, V. Rylov and others) in the eastern part of the lake. Results were published in a monograph compiled by Sokolov (1941).

3. 1934-41: VNIORKh (Leningrad, V. Greze and others) studied zooplankton in the eastern part of the lake. Results were published in a monograph on fishes of the lake (Petrov, 1947).

4. After World War II: the fisheries-oriented zooplankton investigations, conducted by VNIORKh, continued (L. Maksimova, N. Korytova, manuscripts).

5. The 1960s: the Pskov Department of GosNIORKh and the Pskov Pedagogical Institute joined in the zooplankton research of the lake (Denisenko, 1974; Yakovleva \& Ul'yanova, 1980; Ibneeva 1981).

6. From 1962 onward: zooplankton of the lake was studied also by the Võrtsjärv LS (Mäemets, 1966; Mäemets et al., 1996; Haberman, 2001; and others) and the University of Tartu (Virro, 1996). In 1997 research of Protozoa was started (Zingel, 2001, University of Tartu).

On the basis of principal research interests, three stages can be distinguished in the zooplankton research in L. Peipsi: 1909-50 - study of the species composition; 1950-80 - study of abundance and biomass and their seasonal dynamics; and 1980-2000 - study of production and relationships between zooplankton and other links of the ecosystem (bacteria, algae, fishes).

\section{Main conclusions}

1. In the zooplankton of L. Peipsi typical species of eutrophic and oligomesotrophic waters are living side by side. Such coexistence is possible owing to the large size of the lake and its particular transition stage from slightly eutrophic to eutrophic. Two species of oligotrophic waters - Asplanchna herricki 
and Holopedium gibberum - lived in L. Peipsi up to the 1960s, later they have not been encountered there.

2. In zooplankton studies biomass was estimated according to the following scale worked out for Estonian lakes: low $-<1 \mathrm{~g} \mathrm{~m}^{-3}$; moderate $-1-3 \mathrm{~g} \mathrm{~m}^{-3}$; high $-3-10 \mathrm{~g} \mathrm{~m}^{-3}$; very high $->10 \mathrm{~g} \mathrm{~m}^{-3}$. In L. Peipsi the mean biomass in the summers of the $1990 \mathrm{~s}$ was $3.044 \mathrm{~g} \mathrm{~m}^{-3}$, that is relatively high.

3. In 1965-99, the number but not the biomass of zooplankton increased. The number of small-sized zooplankters (especially rotifers) increased, while that of large-sized zooplankters decreased.

4. There is a direct relationship between algae and zooplankton in L. Peipsi: zooplankton consume living algae. An effective pelagial food chain algae $\rightarrow$ zooplankton $\rightarrow$ fish is dominating in the lake. The transformation of solar energy, fixed by algae, to fish production is effective in L. Peipsi, therefore it is one of the richest in fish lakes in Europe, yielding annually up to $31 \mathrm{~kg} \mathrm{ha}^{-1}$ of fish (Pihu, 1996).

\section{Zoobenthos}

\section{Studies}

1. Bottom fauna (particularly molluscs) of the lake has been investigated only since the 1930s.

1935-36: systematic research of zoobenthos started on the Russian side (VNIORKh). High abundance and biomass of zoobenthos (especially Chironomus larvae) as an important fish food was established.

1950-90: similar fishery-directed complex studies were continued at VNIORKh (GosNIORKh) by Ts. Ioffe, M. Strugach, A. Mikhajlov, N. Minina, L. Antipova, and others.

2. 1958-59: monthly monitoring of the life cycles in some oligochaetes began on the Estonian side of the lake (T. Timm, Võrtsjärv LS).

1962: annual zoobenthos studies began (Õ. Tõlp, K. Kangur, T. Timm, V. Timm, H. Timm, Võrtsjärv LS).

1964-91:21-24 monitoring stations covered the whole lake. Since 1992 sampling was continued at 12-13 stations on the Estonian side only (Timm et al., 2001).

3. July-August 1970, 1980, and 1990: shallow-water monitoring was carried out at 50 profiles along the whole shoreline of the lake by IZB and Võrtsjärv LS. In 2000 only the Estonian side of the lake at 17 profiles was monitored.

\section{Main conclusions}

1. L. Peipsi has the richest macrozoobenthos among the large lakes of North Europe: mean biomass $12.7 \mathrm{~g} \mathrm{~m}^{-2}$ in 1964-2000. Rich benthos resources are underconsumed by fish.

2. Chironomidae are dominating in the lake. Their abundance and biomass are rather stable. 
3. No essential changes in the composition and distribution of macrozoobenthos in connection with eutrophication of the lake were observed. Bottom animals are less sensitive to eutrophication than plankton organisms.

4. Dreissena polymorpha, introduced accidentally in the lake in the $1930 \mathrm{~s}$, has become the most significant animal population in L. Peipsi. Its filtering actions may cause biological oligotrophication of the lake.

\section{Fishes and fisheries management}

\section{Studies}

1. 1851-52: four fishery expeditions (K. E. von Baer, 1860) aimed at finding out why the stocks and catches of main commercial fishes (first of all, bream) had become scanty in the lake. Conclusions: the catches of bream had sharply declined mainly due to the intensive use of fine-meshed fishing gear as well as the blocking of normal access for bream to its spawning grounds by large traps.

2. 1912-13: stocks and catches of smelt and other commercial fishes in L. Pihkva by I. Kuznetsov, St. Petersburg.

3. 1935-41: biology and stocks of fishes, fisheries management in the Russian part of the lake by VNIORKh, Leningrad (Petrov, 1947; and others).

4. 1950-91: biology and stocks of fishes, fisheries management in the whole lake, since 1992 in the Russian part of the lake (GosNIORKh, Leningrad, Pskov; by P. Tyurin, N. Malashkin, L. Perminov, V. Kozlov, N. Kontsevaya, and others).

5. 1962-91: inferior and predatory fishes, fisheries management; since 1992 in the Estonian part of the lake (Võrtsjärv LS, Kangur \& Kangur, 1996; Pihu \& Kangur, 2001).

6. Since 1997: fish stocks, fisheries management in the Estonian part of the lake (Estonian Marine Institute, University of Tartu, by T. Saat, M. Vetemaa, V. Vaino, R. Eschbaum, and others).

\section{Main conclusions}

1. Considering annual fish catches (usually 9000-11 $000 \mathrm{t}$ or $25-31 \mathrm{~kg} \mathrm{ha}^{-1}$ ) L. Peipsi surpasses all large lakes in North Europe. The main commercial fishes are smelt, perch, pikeperch, roach, bream, pike, and until the 1990s also vendace. Presently it is changing into a smelt-bream-pikeperch lake.

2. In August 1959 and 1972 mass summer kills of smelt occurred in the lake, caused by severe night-time water anoxia. The stock of smelt was restored in 2-3 years.

3. In 1990 the abundance of vendace dropped sharply in the lake in connection with a serious deterioration of its spawning conditions in successive mild winters (Pihu \& Kangur, 2001). In 1991-94 vendace was not caught but later its stock has somewhat restored.

As a result of intensive use of trawls and fine-meshed Danish seines, the stock of pikeperch was strongly suppressed in the lake in 1957-83. After trawls were prohibited and the number of Danish seines was considerably restricted, the stock 
and catches of pikeperch began to grow rapidly. Since 1989 pikeperch has become the principal export fish in the lake. The increasing trend in the pikeperch stock is supported by spreading eutrophication in the lake, first of all by decreasing water transparency.

\section{REFERENCES}

Baer (Bér), K. E. von. 1860. Investigations on the state of fisheries in Russia, 1. Fishery in Lakes Peipsi and Pskov and in the Baltic Sea. Sankt Peterburg (in Russian).

Bessonov, N. M. \& Vasil'ev, O. A. 1975. Preliminary results of investigation on the balance of organic substance in Lake Pskovsko-Chudskoe. Tr. Pskovsk. otd. GosNIORKh, 1, 44-47 (in Russian).

Davydova, N. N. 1985. Diatoms - Indicators of Natural Conditions of Water Bodies in the Holocene. Nauka, Leningrad (in Russian).

Denisenko, A. I. 1974. Zooplankton of Pskov and Teploe lakes. Izv. GosNIORKh, 83, 43-50 (in Russian).

Haberman, J. 2001. Zooplankton. In Lake Peipsi. Flora and Fauna (Pihu, E. \& Haberman, J., eds.), pp. 50-68. Sulemees Publ., Tartu.

Ibneeva, N. I. 1981. Distribution of planktonic crustaceans in Pskov-Chud Lake. Sb. nauchn. tr. GosNIORKh, 162, 77-88 (in Russian).

Jaani, A. \& Raukas, A. 1999. Lake Peipsi and its catchment area. In Lake Peipsi. Geology (Miidel, A. \& Raukas, A., comps. \& eds.), pp. 9-14. Sulemees Publ., Tallinn.

Kangur, A. \& Kangur, P. 1996. The condition, length and distribution of pikeperch, Stizostedion lucioperca (L.) in Lake Peipsi. Hydrobiologia, 338, 179-183.

Kaputerko, S. A. 1983. Hydrochemical characterization of the lake. In Lake Chudsko-Pskovskoe (Sokolov, A. A., ed.), pp. 116-125. Gidrometeoizdat, Leningrad (in Russian).

Laugaste, R., Nõges, T., Nõges, P., Yastremski, V. V., Milius, A. \& Ott, I. 2001. Algae. In Lake Peipsi. Flora and Fauna (Pihu, E. \& Haberman, J., eds.), pp. 31-49. Sulemees Publ., Tartu.

Loigu, E., Iital, A., Karlova, S., Leisk, Ü., Pachel, K., Schulz, Ü., Trapido, M., Vassiljev, A. \& Veldre, I. 1999. Peipsi valgla reostuskoormus ja jõgede vee kvaliteet. In Peipsi (Pihu, E. \& Raukas, A., eds.), pp. 66-80. Keskkonnaministeeriumi Info- ja Tehnokeskus, Tallinn.

Lokk, S. \& Kisand, V. 1996. Microbiological characteristics and sanitary status of Lake PeipsiPihkva and its inflows in the 1980s. Hydrobiologia, 338, 133-138.

Lokk, S., Kisand, V. \& Piirimäe, K. 2001. Bacterioplankton. In Lake Peipsi. Flora and Fauna (Pihu, E. \& Haberman, J., eds.), pp. 24-30. Sulemees Publ., Tartu.

Mäemets, A. 1966. On summer zooplankton of L. Peipsi-Pihkva. In Hydrobiological Researches, Vol. 4 (Pihu, E. \& Mäting, A., eds.), pp. 80-96. Valgus, Tallinn (in Russian).

Mäemets, A. \& Mäemets, H. 2001. Macrophytes. In Lake Peipsi. Flora and Fauna (Pihu, E. \& Haberman, J., eds.), pp. 9-22. Sulemees Publ., Tartu.

Mäemets, A., Timm, M. \& Nõges, T. 1996. Zooplankton of Lake Peipsi-Pihkva in 1909-1987. Hydrobiologia, 338, 105-112.

Möls, T. \& Saan, T. 1991. Keskkonna monotoonsete muutuste uurimine trendkontrastidega Peipsi näitel. In Kaasaegse ökoloogia probleemid, pp. 114-117. Tartu.

Möls, T., Starast, H., Milius, A. \& Lindpere, A. 1996. The hydrochemical state of Lake PeipsiPihkva. Hydrobiologia, 338, 37-47.

Nazarov, G. V. 1984. Lake Chudsko-Pskovskoe. Chemical composition of water. In Natural Resources of Large Lakes of the USSR and Their Probable Changes (Alekin, O. A., ed.), pp. 110-114. Leningrad (in Russian).

Nedospasova, G. V. 1974. Macrophytes of Lake Pskovsko-Chudskoe. Izv. GosNIORKh, 83, 26-32 (in Russian). 
Nõges, P., Nõges, T. \& Yastremskij, V. V. 1996. Primary production of lake Peipsi-Pihkva. Hydrobiologia, 338, 77-89.

Petrov, V. V. 1947. Factors forming the ichthyofauna of Lake Pskovsko-Chudskoe. Izv. VNIORKh, 26, 3-110 (in Russian).

Pihu, E. 1996. Fishes, their biology and fisheries management in Lake Peipsi. Hydrobiologia, 338, $163-172$.

Pihu, E. \& Haberman, J. (eds.) 2001. Lake Peipsi. Flora and Fauna. Sulemees Publ., Tartu.

Pihu, E. \& Kangur, A. 2001. Fishes and fisheries management. In Lake Peipsi. Flora and Fauna (Pihu, E. \& Haberman, J., eds.), pp. 100-111. Sulemees Publ., Tartu.

Pihu, E. \& Raukas, A. (eds.) 1999. Peipsi. Keskkonnaministeeriumi Info- ja Tehnokeskus, Tallinn.

Samsonov, N. A. 1912. Plankton of Lake Pskov. I. Winter plankton. Tr. promysl.-nauchn. éksped. izuch. Pskovsk. vodoema, 1 (1), 1-16 (in Russian).

Samsonov, N. A. 1914. Plankton of Lake Pskov. II. Spring and summer plankton. Tr. promysl.nauchn. éksped. izuch. Pskovsk. vodoema, 1 (4), 1-18 (in Russian).

Simm, H. 1975. Eesti pinnavete hüdrokeemia. Valgus, Tallinn.

Sokolov, A. A. (ed.) 1941. Lake Chudsko-Pskovskoe. Gosud. Gidrometeorol. Izd., Leningrad (in Russian).

Spindler, J. B. \& Sengbusch, A. 1896. Lake Peipus. Izv. Imper. Russk. geogr. obshch., 32 (4) (in Russian).

Starast, H., Möls, T., Lindpere, A. \& Milius, A. 1999. Hüdrokeemia. In Peipsi (Pihu, E. \& Raukas, A., eds.), pp. 56-65. Keskkonnaministeeriumi Info- ja Tehnokeskus, Tallinn.

Sudnitsõna, D. N. 1990. Peipsi-Pihkva järve kõrgem veetaimestik. In Peipsi järve seisund (Timm, T., ed.), pp. 87-90. Tartu.

Timm, T., Kangur, K., Timm, H. \& Timm, V. 2001. Zoobenthos. In Lake Peipsi. Flora and Fauna (Pihu, E. \& Haberman, J., eds.), pp. 82-99. Sulemees Publ., Tartu.

Tuvikene, H. 1966. Macrophyte vegetation of Lake Peipsi-Pihkva. In Hydrobiological Researches, Vol. 4 (Pihu, E. \& Mäting, A., eds.), pp. 75-79. Valgus, Tallinn (in Russian).

Virro, T. 1996. Taxonomic composition of rotifers in Lake Peipsi. Hydrobiologia, 338, 125-132.

Voronikhin, N. N. 1950. Phytoplankton of lake Pskov. In Cryptogamous Plants, Vol. 5, pp. 5-19. Moskva-Leningrad (in Russian).

Yakovleva, N. A. \& Ul'yanova, R. P. 1980. Seasonal and year to year dynamics of zooplankton in Pskov-Chud lake during the period from 1972 up to 1975. Sb. nauchn. tr. GosNIORKh, 156, 23-26 (in Russian).

Yastremskij, V. V. 1983. Primary production of plankton in Lake Pskovsko-Chudskoe. Sb. nauchn. tr. GosNIORKh, 209, 3-17 (in Russian).

Zingel, P. 2001. Planktonic ciliates (Ciliophora) of Lake Peipsi. In Lake Peipsi. Flora and Fauna (Pihu, E. \& Haberman, J., eds,), pp. 69-73. Sulemees Publ., Tartu.

\section{PEIPSI ÖKOSÜSTEEMI UURIMISE AJALUGU}

\section{Külli KANGUR, Juta HABERMAN, Andu KANGUR, Peeter KANGUR, Anu MILIUS, Helle MÄEMETS, Reet LAUGASTE ja Ervin PIHU}

Peipsi elustiku uurimine algas juba poolteist sajandit tagasi, kompleksseid uurimistöid tehakse 1930. aastatest saadik. Artikkel annab lühiülevaate selle suure ja väärtusliku piirijärve vee keemilise koostise, suurtaimestiku, bakter-, füto- ja zooplanktoni, zoobentose, kalade ning kalanduse uurimisest. On mainitud ka nende uurimistööde tähtsamaid tulemusi. 